\title{
Hasil Belajar Matematika Model Pembelajaran Creative Problem Solving Berbantuan Media Pembelajaran
}

\author{
Marniati*1, Jahring ${ }^{2}$ \\ 1,2Pendidikan Matematika Universitas Sembilanbelas November Kolaka; \\ e-mail: *21 bungaitb@gmail.com, 2jahring@usn.ac.id
}

\begin{abstract}
Abstrak
Penelitian ini merupakan penelitian eksperimen yang bertujuan untuk mengetahui efektivitas model pembelajaran creative problem solving (CPS) berbantuan media pembelajaran terhadap hasil belajar siswa. Populasi penelitian ini adalah siswa Kelas IX SMP Negeri 1 Baula. Menggunakan cluster random sampling diperoleh 2 kelas sampel sebagai kelas eksperimen dengan model pembelajaran CPS berbantuan media pembelajaran dan kelas kontrol dengan pembelajaran konvensional. Desain penelitian berupa posttest yang diberikan setelah diberikan treatment atau perlakuan berupa penerapan model pembelajaran CPS dan pembelajaran konvensional. Secara deskriptif menunjukkan bahwa dari 20 orang siswa pada kelas eksperimen dengan mean 66,5, varians 84,26, dan standar deviasi 9,18, sedangkan pada kelas kontrol yang berjumlah 20 orang dengan mean 60, 95, varians 111,63, dan standar deviasi 10,66. Ditinjau dari proses dan keterlaksanaan pembelajaran, kedua kelas menunjukkan kriteria aktif dengan persentase sebesar 75\% - 85\%. Secara inferensial dengan menggunakan uji-t, $t_{\text {hitung }}=1,773>t_{\text {tabel }}=1,685$ yang mengindikasikan bahwa terdapat perbedaan yang signifikan antara hasil belajar matematika dengan model pembelajaran CPS dan pembelajaran konvensional. Sehingga disimpulkan bahwa model pembelajaran CPS berbantuan media pembelajaran efektif terhadap hasil belajar matematika siswa kelas IX SMP Negeri 1 Baula.
\end{abstract}

Kata kunci : Creative problem solving, Media pembelajaran, Hasil belajar

\section{PENDAHULUAN}

Dewasa ini, ilmu pengetahuan dan teknologi berkembang dengan pesatnya disegala bidang kehidupan, salah satunya adalah di bidang pendidikan. Berbagai inovasi dan kreasi telah dilakukan oleh pendidik, salah satunya adalah media pembelajaran. Hanafia, dkk (2010) menjelaskan bahwa media pembelajaran merupakan segala bentuk alat perangsang dan alat yang disediakan guru untuk mendorong siswa belajar secara cepat, tepat, mudah, benar dan tidak terjadinya verbalisme. Selain pendapat tersebut, (Prihatin \& Ridaswati, 2008) juga menerangkan bahwa media pembelajaran adalah alat yang dapat digunakan untuk membantu siswa dalam memahami dan memperoleh informasi yang dapat didengar ataupun dilihat oleh panca indera sehingga pembelajaran dapat berhasil dan berdaya guna. Salah satu kelebihan media pembelajaran adalah metode mengajar akan lebih bervariasi sehingga siswa tidak akan mudah bosan, (Russefendi, 2001). Oleh karena itu, media pembelajaran harus dikombinasikan dengan suatu model pembelajaran agar lebih variatif, Pemilihan media pembelajaran juga harus tepat berdasarkan modalitas belajar yang dimiliki oleh siswa. Karena pemilihan media pembelajaran ataupun model pembelajaran yang tepat sesuai dengan modalitas belajar dapat meningkatkan hasil belajar, (Jahring \& Chairuddin, 2019).

Kegiatan observasi yang telah dilakukan di SMP Negeri 1 Baula menunjukkan bahwa sebagian besar siswa mengalami masalah, seperti malas belajar, lambatnya daya tangkap siswa terhadap materi pelajaran, malu bertanya dan tidak memperhatikan dengan baik guru saat mengajar, sehingga mempengaruhi hasil

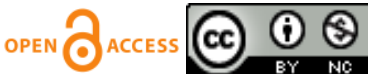


https://jurnal.unsulbar.ac.id/index.php/saintifik

belajar siswa yang bersangkutan. Hal tersebut didukung dengan adanya data nilai ulangan harian siswa yang disajikan dalam tabel 1 berikut ini.

Tabel 1 Rata-Rata Ulangan Harian Siswa Kelas IX SMP Negeri 1 Baula

\begin{tabular}{|c|c|c|}
\hline Kelas & Jumlah Siswa & Rata-Rata Ulangan Harian \\
\hline $\mathrm{IX}_{\mathrm{A}}$ & 20 & 59,65 \\
\hline $\mathrm{IX}_{\mathrm{B}}$ & 20 & 59,54 \\
\hline $\mathrm{IX}_{\mathrm{C}}$ & 20 & 59,00 \\
\hline $\mathrm{IX}_{\mathrm{D}}$ & 18 & 60,55 \\
\hline
\end{tabular}

(Sumber : SMP Negeri 1 Baula)

Rendahnya hasil belajar siswa kelas IX SMP Negeri 1 Baula disebabkan oleh pembelajaran yang diterapkan oleh guru yang masih bersifat konvensional. Melihat kondisi dan fakta di SMP Negeri 1 Baula, peneliti berpikir untuk menerapkan suatu pembelajaran yang dapat mengatasi semua masalah-masalah yang ada, model pembelajaran yang bisa merangsang minat belajar siswa, membuat siswa lebih mudah memahami materi pelajaran, dan mampu bertanggungjawab terhadap masalah yang diberikan oleh guru. Salah satu model pembelajaran yang bisa diterapkan adalah model pembelajaran Creative Problem Solving (CPS), yaitu suatu model pembelajaran yang melakukan pemusatan pada pengajaran dan keterampilan pemecahan masalah yang diikuti dengan penguatan keterampilan. Ketika dihadapkan dengan suatu pertanyaan, siswa dapat melakukan keterampilan memecahkan masalah untuk memilih dan mengembangkan tanggapannya. Tidak hanya dengan menghafal dan berfikir, keterampilan memecahkan masalah memperluas proses berfikir, (Shoimin, 2014). Menciptakan pembelajaran yang menyenangkan tidak hanya menerapkan model pembelajaran dalam proses belajar mengajar, melainkan juga didukung dengan adanya media pembelajaran, (Yuliani, Kanzunnudin, \& Rahayu, 2018). Oleh karena itumodel pembelajaran CPS diterapkan berbantuan media pembelajaran. pemilihan media pembelajaran ini diharapkan mampu memberikan efektifitas hasil belajar yang baik kepada siswa, karna media pembelajaran merupakan alat yang menyampaikan pesan-pesan pembelajaran sehingga dapat merangsang pikiran, perasaan, perhatian, dan minat serta perhatian siswa sedemikian rupa sehingga proses belajar terjadi.

Penelitian tentang CPS telah banyak dilakukan, seperti (Sospolita, Aisyah, \& Widada, 2019) yang melihat penerapan model CPS dengan teknik probing pada pembelajaran matematika dengan hasil yang signifikan tuntas memenuhi KKM serta aktivitas siswa pun dalam kategori baik. Kemudian (Utami, Ainy, \& Mursyidah, 2019) menganalisis efektivitas model pembelajaran CPS terhadap hasil belajar siswa pada materi luas permukaan bangun ruang sisi datar yang menunjukkan CPS efektif, dan (Effendi \& Fatimah, 2019) melihat implementasi model pembelajaran CPS untuk siswa kelas awal sekolah menengah kejuruan. Beberapa penelitian tersebut tidak dikombinasikan dengan media pembelajaran yang dapat merangsang pikiran, perasaan, perhatian, dan minat serta perhatian siswa. Oleh karena itu, penelitian ini menerapkan model pembelajaran CPS dengan bantuan media pembelajaran matematika.

\section{METODE PENELITIAN}

Jenis penelitian yang digunakan adalah eksperimen dengan metode penelitian true eksperimental design. Desain penelitian yang digunakan adalah posttest only control group design, artinya dalam desain ini menggunakan dua kelompok yang terdiri dari satu kelas eksperimen dan satu kelas kontrol dan dipilih secara random $(\mathrm{R})$, diberikan treatmnet, lalu diberikan posttest kemudian dianalisis hasilnya. 
https://jurnal.unsulbar.ac.id/index.php/saintifik

Tabel 2 Desain Penelitian Posttest Only Control Group Design

\begin{tabular}{|c|c|c|}
\hline $\mathrm{R}$ & $\mathrm{X}$ & $\mathrm{O}_{1}$ \\
\hline $\mathrm{R}$ & - & $\mathrm{O}_{2}$ \\
\hline
\end{tabular}

(Sugiyono, 2017)

Keterangan:

$\mathrm{R}:$ Random

$\mathrm{X} \quad$ : Treatment dengan Model Pembelajaran CPS Berbantuan Media Pembelajaran

$\mathrm{O}_{1} \quad$ : Hasil Posttest Siswa pada Model Pembelajaran CPS Berbantuan Media Pembelajaran

$\mathrm{O}_{2} \quad$ : Hasil Posttest Siswa pada Pembelajaran Konvensional

Penelitian efektivitas model pembelajaran CPS berbantuan media pembelajaran ini dilaksanakan di kelas IX SMP Negeri 1 Baula. Penelitian ini dilaksanakan pada semester ganjil tahun pelajaran 2018/2019 yang terdiri dari empat kelas dengan jumlah siswa 78 orang. Menggunakan cluster random sampling, ditetapkan kelas $\mathrm{IX}_{\mathrm{c}}$ sebagai kelas eksperimen yang diajar dengan model pembelajaran CPS berbantuan media pembelajaran dan kelas $\mathrm{IX}_{\mathrm{B}}$ sebagai kelas kontrol.

Penelitian ini diawali dengan pemilihan sampel dan materi yang akan digunakan, selanjutnya disusun perangkat pembelajaran yang disesuaikan dengan model pembelajaran berbantuan media pembelajaran, membuat media pembelajaran dan instrumen penelitian yang telah divalidasi. Pembelajaran dilakukan sebanyak 5 kali, dengan pertemuan pertama sampai pertemuan keempat dilaksanakan dengan menerapkan model pembelajaran CPS berbantuan media pembelajaran pada kelas eksperimen dan pembelajaran konvensional pada kelas kontrol. Dalam pelaksanaan pembelajaran pada setiap pertemuan dilakukan observasi aktivitas siswa dan keterlaksanaan pembelajaran yang dilakukan oleh observer. Pertemuan kelima diberikan posttest, selanjutnya hasilnya dianalisis secara deskriptif dan inferensial. Instrumen yang digunakan berupa lembar observasi aktivitas siswa, lembar observasi keterlaksanaan pembelajaran, soal tes hasil belajar matematika siswa.

\section{HASIL DAN PEMBAHASAN}

Hasil penelitian ini meliputi hasil analisis deskriptif dan hasil analisis inferensial, yaitu:

3.1. Analisis Deskriptif

3.1.1. Analisis Hasil Belajar Matematika Siswa

Analisis hasil belajar matematika siswa dimaksudkan untuk memberikan gambaran karakteristik dan perbedaan model pembelajaran Creative Problem Solving (CPS) berbantuan media pembelajaran dengan model pembelajaran konvensional yang dapat dilihat melalui nilai rata-rata (mean), varians, dan standar deviasi. Hasilnya dapat dilihat pada tabel 3.

Tabel 3 Hasil Belajar Matematika Siswa

\begin{tabular}{|c|c|c|}
\hline Statistik & Kelas Eksperimen & Kelas Kontrol \\
\hline $\mathrm{N}$ & 20 & 20 \\
\hline Mean & 66,50 & 60,95 \\
\hline Varians & 84,26 & 111,63 \\
\hline Standar Deviasi & 9,18 & 10,56 \\
\hline
\end{tabular}

\subsubsection{Analisis Lembar Observasi Keterlaksanaan Pembelajaran}

Lembar observasi aktivitas guru digunakan untuk mengetahui, kemampuan guru dalam mengelola pembelajaran sesuai dengan sintaks yang ada pada kedua model pembelajaran Creative Problem Solving (CPS) berbantuan media pembelajaran dan pembelajaran konvensional. Hasil analisis lembar observasi dapat dilihat pada tabel 4. 
https://jurnal.unsulbar.ac.id/index.php/saintifik

Tabel 4 Hasil Lembar Observasi Keterlaksanaan Pembelajaran oleh Guru

\begin{tabular}{|c|c|c|c|c|c|c|}
\hline \multirow{2}{*}{ Kelas } & \multicolumn{4}{|c|}{ Pertemuan } & \multirow{2}{*}{ Rata-Rata (\%) } & \multirow{2}{*}{ Kategori } \\
\hline & $1(\%)$ & $2(\%)$ & $3(\%)$ & $4(\%)$ & & \\
\hline Eksperimen & 94,11 & 88,23 & 82,35 & 94,11 & 89,70 & Sangat Tinggi \\
\hline Kontrol & 88,88 & 77,77 & 77,77 & 88,88 & 83,32 & Tinggi \\
\hline
\end{tabular}

Hasil analisis lembar observasi keterlaksanaan pembelajaran oleh guru disajikan dalam bentuk diagram berikut.

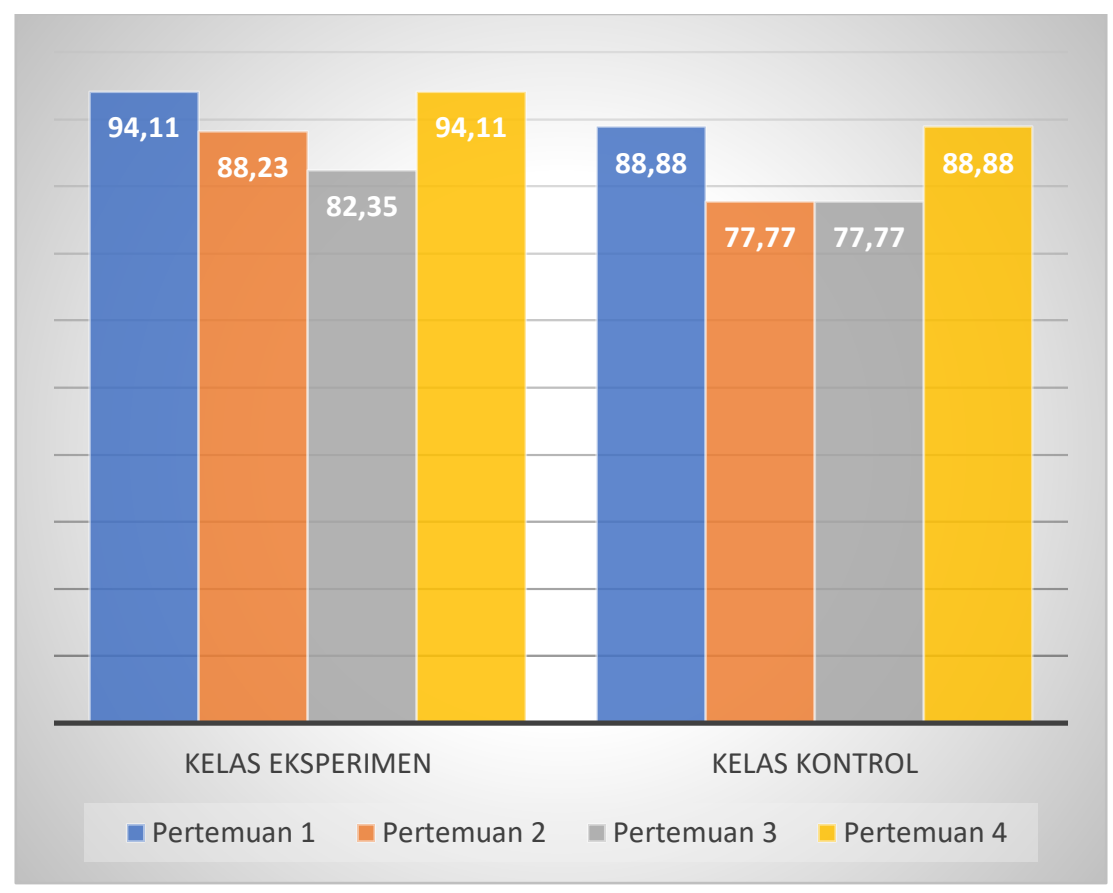

Gambar 1 Hasil lembar observasi keterlaksanaan pembelajaran oleh guru

Rata-rata persentase keterlaksanaan pembelajaran oleh guru dalam proses pembelajaran menggunakan model pembelajaran CPS berbantuan media pembelajaran sebesar $89,70 \%$ dan rata-rata persentase keterlaksanaan pembelajaran oleh guru dengan pembelajaran konvensional sebesar 83,32\%. Hal ini menunjukkan bahwa, baik pada kelas eksperimen maupun pada kelas kontrol, guru sudah melakukan pembelajaran sesuai dengan langkahlangkah pembelajaran CPS berbantuan media pembelajaran.

\subsubsection{Analisis Lembar Observasi Aktivitas Siswa}

Lembar observasi aktivitas siswa digunakan untuk mengetahui keaktifan siswa selama proses pembelajaran berlangsung. Hasil analisis lembar observasi tersebut dapat dilihat pada tabel 5 .

Tabel 5 Hasil Lembar Observasi Aktivitas Siswa

\begin{tabular}{|c|c|c|c|c|c|c|}
\hline \multirow{2}{*}{ Kelas } & \multicolumn{4}{|c|}{ Pertemuan } & \multirow{2}{*}{ Rata-Rata (\%) } & \multirow{2}{*}{ Kategori } \\
\hline & $1(\%)$ & $2(\%)$ & $3(\%)$ & $4(\%)$ & & \\
\hline Eksperimen & 78 & 80 & 78 & 90 & 81,50 & Tinggi \\
\hline Kontrol & 66,66 & 73,33 & 70 & 80 & 72,50 & Tinggi \\
\hline
\end{tabular}


Hasil analisis lembar observasi aktivitas siswa disajikan dalam bentuk diagram berikut.

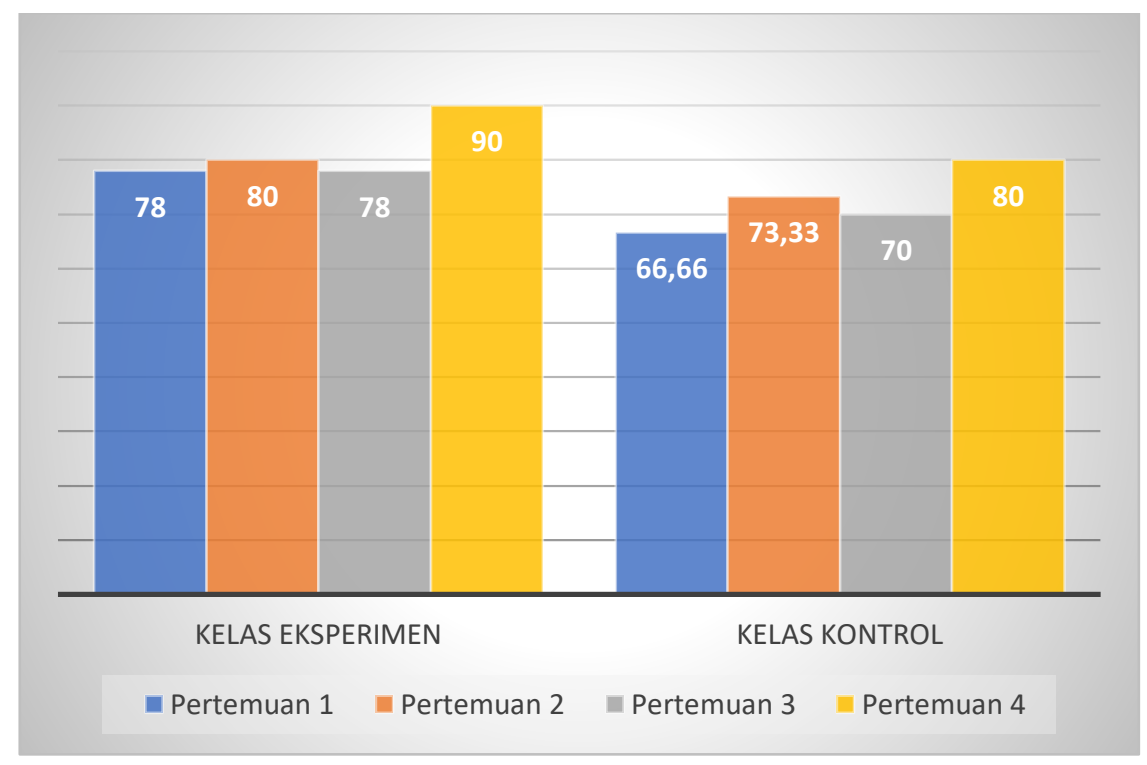

Gambar 2 Hasil Lembar Observasi Aktivitas Siswa

Hasil pengamatan observer terhadap aktivitas siswa dalam proses pembelajaran baik pada kelas eksperimen maupun kelas kontrol, masing-masing selama 4 pertemuan menunjukkan bahwa semua aspek yang diamati secara umum terlaksana dengan baik. Nilai rata-rata persentase aktivitas siswa dalam proses pembelajaran menggunakan model pembelajaran Creative Problem Solving (CPS) berbantuan media pembelajaran sebesar $81,5 \%$. Sedangkan nilai rata-rata persentase aktivitas siswa dalam proses pembelajaran menggunakan pembelajaran konvensional sebesar $72,50 \%$. Dari nilai rata-rata persentase aktivitas siswa dalam proses pembelajaran tersebut menunjukkan bahwa aktivitas siswa dalam proses pembelajaran, baik pada kelas eksperimen maupun kelas kontrol termasuk dalam kategori aktif.

\subsection{Analisis Inferensial}

Analisis inferensial dimaksudkan untuk menguji hipotesis perbedaan perlakuan atau perbedaan antara hasil belajar matematika siswa setelah diterapkan model pembelajaran creative problem solving (CPS) berbantuan media pembelajaran dengan pembelajaran konvensional. Sebelum dilakukannya uji hipotesis, terlebih dahulu dilakukan uji normalitas dan uji homogenitas data penelitian. Hasil uji normalitas diperoleh kedua kelas, baik eksperimen maupun kontrol berdistribusi normal. Selanjutnya berdasarkan hasil uji homogenitas menggunakan uji $\mathrm{F}$ diperoleh data penelitian homogen. Data dalam penelitian ini memenuhi syarat normal dan homogen, sehingga dilanjutkan dengan uji hipotesis (uji-t). Hipotesis yang diuji adalah

$$
H_{0}: \mu_{1} \leq 0 \text { lawan } H_{1}: \mu_{1}>0
$$

dengan kriteria pengujian adalah tolak $H_{0}$ jika $\mathrm{t}_{\text {hitung }}>\mathrm{t}_{\text {tabel }}$, dan tolak $H_{l}$ jika $\mathrm{t}_{\text {hitung }}<\mathrm{t}_{\text {tabel }}$ pada taraf siginifikansi $(\alpha=0,05)$. Berdasarkan hasil analisis inferensial, diperoleh nilai $\mathrm{t}_{\text {hitung }}=1,773>\mathrm{t}_{\text {tabel }}=1,685$, maka $H_{0}$ ditolak dan $H_{1}$ diterima. Dengan demikian, dapat disimpulkan hasil belajar matematika siswa dengan model pembelajaran CPS berbantuan media pembelajaran lebih efektif dari pada pembelajaran konvensional pada siswa kelas IX SMP Negeri 1 Baula.

Berdasarkan hasil penelitian yang telah diuraikan sebelumnya diketahui bahwa proses pembelajaran model pembelajaran Creative Problem Solving (CPS) berbantuan media pembelajaran dapat meningkatkan hasil belajar matematika siswa kelas IX SMP Negeri 1 Baula. Hal ini berdasarkan data yang menunjukkan nilai rata-rata sebesar 66,50, standar deviasi sebesar 9,18, varians sebesar 84,26 dan serta pada hasil pengujian hipotesis yang menggunakan uji-t pada taraf signifikan $\alpha=0,05$ diperoleh nilai $\mathrm{t}_{\text {hitung }}=1,773>\mathrm{t}_{\text {tabel }}=1,685$. Karena $t_{\text {hitung }}>t_{\text {tabel, }}$, ini berarti bahwa terdapat perbedaan yang signifikan antara model pembelajaran Creative Problem Solving (CPS) berbantuan media pembelajaran dengan pembelajaran konvensional. 
https://jurnal.unsulbar.ac.id/index.php/saintifik

Meningkatnya hasil belajar matematika siswa disebabkan oleh adanya penerapan model pembelajaran creative problem solving (CPS) berbantuan media pembelajaran. Model pembelajaran CPS berbantuan media pembelajaran merupakan model pembelajaran yang mengupayakan memecahkan suatu permasalahan dengan cara yang kreatif, Yuliani, dkk (2018). Sehingga setiap permasalahan dalam matematika bisa dipecahkan, minat belajar pun meningkat, serta materi menjadi mudah untuk dipahami.

\section{KESIMPULAN}

Berdasarkan rata-rata nilai hasil belajar matematika siswa yang diajar dengan model pembelajaran Creative Problem Solving (CPS) berbantuan media pembelajaran lebih tinggi dibanding rata-rata hasil belajar matematika siswa yang diajar dengan menggunakan pembelajaran konvensional. Hal ini berarti model pembelajaran Creative Problem Solving (CPS) berbantuan media pembelajaran lebih baik daripada pembelajaran konvensional. Sehingga dapat disimpulkan bahwa model pembelajaran Creative Problem Solving (CPS) berbantuan media pembelajaran lebih efektif dibandingkan dengan pembelajaran konvensional terhadap hasil belajar matematika siswa kelas IX SMP Negeri 1 Baula.

\section{DAFTAR PUSTAKA}

Effendi, A., \& Fatimah, A. T. 2019. Implementasi Model Pembelajaran CreativeProblem Solving untuk Siswa Kelas Awal Sekolah Menengah Kejuruan. TEOREMA: Teori dan Riset Matematika, Vol. 4, No. 2, hal. 8998.

Hanafia, N., Suhana, C., \& Idi, A. 2010. Konsep Strategi Pembelajaran. Bandung: Refika Aditama.

Jahring, \& Chairuddin. 2019. Preferensi Modalitas Belajar Mahasiswa Angkatan 2016 Program Studi Pendidikan Matematika Universitas Sembilanbelas November Kolaka. SQUARE: Journal of Mathematics and Mathematics Education, Vol. 1, No. 1, hal. 27-32. doi:10.21580/square.2019.1.1.4039

Prihatin, E., \& Ridaswati. 2008. Guru Sebagai Fasilitator. Bandung: Karsa Mandiri Persada.

Russefendi. 2001. Pemanfaatan Media Pembelajaran. Jakarta: Bumi Aksara.

Shoimin, A. 2014. 68 Model Pembelajaran Inovatif dalam kurikulum 2013. Jakarta: Ar-Ruzz Media.

Sospolita, N., Aisyah, S., \& Widada, W. 2019. Penerapan Model Creative Problem Solving dengan Teknik Probing pada Pembelajaran Matematika. Jurnal Pendidikan Matematika Raflesia, Vol. 4, No. 2, hal. 194201. doi:10.33449/jpmr.v4i2.9818

Sugiyono. 2017. Metode Penelitian Kuantitatif, Kualitatif, dan $R \&$ D. Bandung: Alfabeta.

Utami, F., Ainy, C., \& Mursyidah, H. 2019. Efektivitas Penerapan Model Pembelajaran Creative Problem Solving (CPS) Terhadap Hasil Belajar Siswa pada Materi Luas Permukaan Bangun Ruang Sisi Datar. Jurnal Math Educator Nusantara: Wahana Publikasi Karya Tulis Ilmiah Di Bidang Pendidikan Matematika, Vol. 5, No. 01, hal. 01-13. doi:10.29407/jmen.v5i01.12332

Yuliani, I., Kanzunnudin, M., \& Rahayu, R. 2018. Penerapan Model Creative Problem Solving Berbantuan Media Bongkar Pasang untuk Peningkatan Berpikir Kreatif Matematika Siswa Sekolah Dasar. ANARGYA: Jurnal Ilmiah Pendidikan Matematika, Vol. 1, No. 1, hal. 29-36. doi:10.24176/anargya.v1i1.2283 